\title{
Dietary intake in 6-year-old children from southern Poland: part 1 - energy and macronutrient intakes
}

Sylwia Merkiel

\begin{abstract}
Background: The studies on dietary intake in Polish children are sparse and the information about dietary intake in 6 -year-olds in Europe is limited. The published studies on dietary intake in children rarely provide information on the intake of animal protein, plant protein and water. The purpose of the study was to analyse energy and macronutrient intakes in 6-year-old children from southern Poland.

Methods: The studied population comprised 120 children, 64 girls and 56 boys. Energy and macronutrient intakes were estimated from a three-day food record. Weight and height were measured, and body mass index was calculated.

Results: Intakes of energy ( $\mathrm{k}, \mathrm{kcal})$, plant protein ( $\mathrm{g}$ ), total fat (g), saturated fatty acids ( $\mathrm{g}, \%$ of energy, $\mathrm{g} / 1000 \mathrm{kcal})$, monounsaturated fatty acids $(\mathrm{g})$ and starch ( $\mathrm{g}, \%$ of energy, $\mathrm{g} / 1000 \mathrm{kcal}$ ) were significantly higher in boys, while intakes of sucrose (\% of energy, $\mathrm{g} / 1000 \mathrm{kcal}$ ) and total water $(\mathrm{g} / 1000 \mathrm{kcal}$ ) were significantly higher in girls. The children's diets were characterised by excessive intake of total fat, saturated fatty acids, sucrose, and by inadequate intake of polyunsaturated fatty acids, available carbohydrates and starch.

Conclusions: The observed adverse characteristics of the children's diets are similar to those observed in the diets of children in other European countries and show the need to work out a common educational programme to improve nutrition in young European children. It is also important to provide the lacking information about the intake of animal protein, plant protein and water in young children.
\end{abstract}

Keywords: Children, Dietary intake, Energy, Macronutrients, Nutrition, Diet

\section{Background}

Adequate dietary intake is of vital importance to children's growth and development, not only in physiological terms but also mental and behavioural. Both excessive and inadequate intake of energy or nutrients may have detrimental influence on children's health and predisposes to diet-related diseases, such as hypertension, atherosclerosis, obesity, osteoporosis and type 2 diabetes later in life. This means that the prevention of these diseases should start as early as in childhood [1]. According to the Institute for Health Metrics and Evaluation [2], among the risk factors for death in both men and women all over Europe, inappropriate dietary intakes rank highest, followed by high blood pressure, while ischaemic heart disease and stroke are the two most common causes of death. Therefore, screening

Correspondence: sylwiamerkiel@awf.poznan.pl

Food and Nutrition Department of the Eugeniusz Piasecki University School of Physical Education in Poznan, Poland, Królowej Jadwigi 27/39 Street, Poznan, 61-871, Poland children for energy and nutrient inadequacies is of particular relevance to public health and to preventing diet-related diseases in population.

One of the crucial periods in a child's life is the age of six years. In Poland and some European countries, such as Estonia, Finland and Sweden, this is the last year of preschool attendance and thus the time when the child should attain the so called 'school readiness' in physical, mental and emotional terms [3,4]. In other European countries, such as Belgium, France, Germany, Portugal or Spain, the age of six years is the time of attending the first class at school where the child needs to cope with the new challenges in the new environment. Both to attain the school readiness and to perform well at school, adequate dietary intakes should be provided for all children.

In the literature published after the year 2000, no publications were found on dietary intakes of 6-year-old children only. Usually, 6-year-olds are included in populations of 
wide age ranges and the results are reported for subgroups within these populations. In Poland, only two studies reported dietary intake of children aged 6 years or less. This is a study on 3-year-old children [5] and a national study on a representative sample which included 4-6-year-old children [6]. There is more information about dietary intake of children from other European countries. The population study of children and adolescents in Great Britain, called the National Diet and Nutrition Survey of young people aged 4-18 years, reported dietary intake for the subgroup aged 4-6 years [7]. In another British population study, the National Diet and Nutrition Survey Rolling Programme 2008/2009 - 2010/2011 [8], 6-year-old children were also included, however, in a subgroup of 4-10-year-olds. In a Belgian study on children aged 2.5-6.5 years $[9,10]$, dietary intake was presented for a subgroup of children aged 4-6.5 years. Quite narrow age ranges were applied in a Greek study on Cretan children aged 5.7-7.6 years [11] and in a Spanish study on 6-7-year-old children [12,13]. Another Spanish study, on 2-24-year-olds [14], reported dietary intake in a subgroup of 6-9-year-old children. In a French study [15], dietary intake of 5-11-year-olds was presented. Information about energy and nutrient intakes in children outside Europe include American children from the National Health and Nutrition Examination Survey for the U.S. population [16] where the widest age ranges of subgroups were applied: less than 6years and 6-11 years. In all of these studies, except for the Spanish study on 6-7-year-olds [12,13], dietary intake was presented according to gender.

What all of the abovementioned studies have in common is analysing various sets of energy and macronutrients. Only one of these studies [9] provided information about water intake, only two $[6,10]$ reported intake of animal and plant protein and only in one study [11] nutrient density was analysed.

In the times of globalisation it is particularly important to obtain detailed information about dietary intake of children from various countries. Therefore, the aim of this study was to analyse energy and macronutrient intakes in 6-year-old children from southern Poland, including intake of animal protein, plant protein and water, as well as nutrient density.

\section{Methods}

\section{Subjects}

The target population for this study were all children who attended the last grade in the preschools associated with the Nowy Sacz League of Preschools and Schools Promoting Health. The aim of the League is to popularise a healthy lifestyle, including a balanced diet, according to the programme of health promotion for preschools recommended by the Polish Ministry of Education. There were eight preschools associated with the League, all of them located in Nowy Sacz and the vicinity, a mountainous region in southern Poland. The directors of all the preschools agreed to take part in the study.

Parents of all the children who attended the last grade, a total of 253 6-year-old children, were invited to take part in the study. Parents of 149 children provided written consent. Twenty eight children who suffered from diabetes, followed special diets because of food allergies or were handicapped were excluded from the analysis of the results. Also one underreporter was excluded from further analysis. The underreporter was identified using the method described in the section Energy and macronutrient intakes [17]. Thus, the final population comprised 120 children, 64 girls and 56 boys. There were no siblings within the studied population.

Parents filled in questionnaires on socio-demographic characteristics of the children and their families $[18,19]$. The study was approved by the Bioethics Committee of the Poznan University of Medical Sciences.

\section{Energy and macronutrient intakes Data collection}

Energy and macronutrient intakes in the studied children were estimated from a three-day food record completed by parents and preschool staff. The days were determined in advance and included two preschool days and one free day (Sunday). Both parents and preschool staff were instructed how to fill in the food diaries. They provided detailed information on the time of consuming each meal, food or beverage, on the way of preparing meals (recipe, ingredients, cooking methods, etc.) and portion sizes which were measured either in grams or in typical household measures. Parents were also asked to record any supplements taken by their children.

\section{Dietary assessment}

Energy and macronutrient intakes were calculated using the Dieta computer programme, version 4.0, worked out by the National Food and Nutrition Institute in Warsaw, Poland. This programme is the best one in Poland so far, offering the possibility to calculate intake of energy and as many as 89 nutrients. The Dieta contains food composition database based on Polish food composition tables [20]. The database includes nutritional value not only of foodstuffs, but also of typical Polish dishes. The user may modify some ingredients of a dish (for example the kind of fat/oil used for frying) depending on the type of ingredients used by the studied person. Moreover, it is possible to calculate nutritional value of any dish using the recipe provided by the studied person. The programme estimates the changes of nutritional value by calculating the losses of nutrients resulting from food processing. The database contains nutritional value of supplements which are available in Poland. 
Energy intake was expressed both in kcal and in $\mathrm{kJ}$ for the reason of easy comparison to the results of those studies where only joules (either kJ of MJ) or only kcal were used. Total protein intake was calculated per $\mathrm{kg}$ of body weight using the Microsoft Excel 2010. It is important to mention that the Dieta calculates not only total protein intake but also animal and plant protein intakes. Additional calculations were performed in the Excel to obtain animal and plant protein intakes expressed as \% of total protein intake. Energy from total protein, total fat and available carbohydrates was obtained from the Dieta computer programme, while energy from fatty acids, lactose, sucrose and starch was calculated using the Excel. Total carbohydrate intake calculated by the Dieta based on Polish food composition tables was derived 'by difference' [20]. This method of deriving total carbohydrates is still used in many countries [21]. Additionally, available carbohydrate intake was calculated as the difference between total carbohydrates and dietary fibre using the Excel. Dietary fibre intake calculated by the Dieta means dietary fibre determined using enzymatic-gravimetric method (AOAC 1990) [20]. Total water intake calculated by the programme includes both water from beverages and water from food. Nutrient densities were estimated as amounts per $1000 \mathrm{kcal}(4185 \mathrm{~kJ})$ of energy intake.

\section{Underreporting of energy intake}

To identify underreporters, the ratio of energy intake to predicted basal metabolic rate (EI: BMR) was computed [17]. Basal metabolic rate (BMR) was calculated using gender- and age-dependent Oxford predictive equations from weight alone, since no significant difference was reported in predicting BMR with the inclusion of height [22]. Records with EI: BMR ratios up to 1.01 for girls and 1.04 for boys were considered as not plausible measurements of the actual three-day energy intake [17]. In the studied population, one boy with EI:BMR ratio below the abovementioned cut-off value was identified and was excluded from further analysis.

\section{Comparison with nutritional guidelines}

Since each individual's energy requirement depends on numerous factors [23] and the best indicator of the adequacy or inadequacy of habitual energy intake is body weight $[23,24]$, BMI was calculated and assessed as described in the section Anthropometric measures in order to conclude whether energy intake was adequate. Energy intake from macronutrients as well as cholesterol intake were compared to those recommended in the prevention of diet-related diseases [25] as in the previous article [26]. Protein intake $(\mathrm{g} / \mathrm{kg}$ ) was compared to the Estimated Average Requirement (EAR) and dietary fibre and total water intakes - to Adequate Intake (AI) for Polish population worked out by the National Food and Nutrition Institute in Warsaw [27].

\section{Anthropometric measures}

Weight and height were measured, and body mass index (BMI) was calculated. BMI was classified to percentile ranges on the basis of the tables provided by Kuczmarski et al. [28]. The percentile ranges were called using the terminology recommended by the International Obesity Task Force [29]: below the $5^{\text {th }}$ percentile - underweight; from the $5^{\text {th }}$ to the $84^{\text {th }}$ percentile - healthy weight; from the $85^{\text {th }}$ to the $94^{\text {th }}$ percentile - overweight; the $95^{\text {th }}$ percentile or above - obesity [30].

\section{Statistical analysis}

Statistical analysis was carried out by means of the IBM SPSS Statistics computer programme, version 19 (Chicago, IL, USA). The studied population was divided according to gender. Means and standard deviations (SD) were calculated for parents' age. For energy and macronutrient intakes, means, standard deviations, medians and standard errors (SE) were calculated. In addition, the percentages of children with nutrient intakes below or above the recommendations were calculated to investigate the prevalence of inadequate intake.

Qualitative variables were presented in contingency tables. Statistical significance was determined using Pearson's chi-square test. Quantitative variables were first analysed using the Shapiro-Wilk statistic for testing normality. The level of significance was set at $P \leq 0.05$. The unpaired Student's $t$ test for normally distributed variables and the non-parametric Mann-Whitney $U$ test for skewed variables were used to investigate statistically significant differences. The level of significance was set at $P \leq 0.05$.

\section{Results}

Table 1 shows socio-demographic characteristics of the studied 6-year-old children and their families. No statistically significant differences between girls and boys were observed.

Table 2 presents energy intake in the studied 6-yearold children according to the percentile categories for BMI. Although these results did not reach statistical significance, it is important to mention that energy intake increased through the percentile categories, except for the $95^{\text {th }}$ percentile and above.

Table 3 shows energy and macronutrient intakes in the studied 6-year-old children. Intakes of energy (kJ, kcal), plant protein $(\mathrm{g})$, total fat $(\mathrm{g})$, saturated fatty acids (g,\% of energy, g/1000 kcal), monounsaturated fatty acids (g) and starch (g, \% of energy, g/1000 kcal) were significantly higher in boys, while intakes of sucrose (\% of energy, g/1000 kcal) and total water $(\mathrm{g} / 1000 \mathrm{kcal})$ were significantly higher in 
Table 1 Socio-demographic characteristics of the studied 6-year-old children and their families

\begin{tabular}{|c|c|c|c|}
\hline Variable & $\begin{array}{c}\text { Girls } \\
(n=64)\end{array}$ & $\begin{array}{c}\text { Boys } \\
(n=56)\end{array}$ & $\begin{array}{c}\text { All children } \\
(n=120)\end{array}$ \\
\hline Mother's age (years) & $33.0 \pm 5.3^{1}$ & $33.8 \pm 5.5^{1}$ & $33.4 \pm 5.4^{1}$ \\
\hline Father's age (years) & $36.0 \pm 6.5^{1}$ & $35.9 \pm 6.4^{1}$ & $36.0 \pm 6.4^{1}$ \\
\hline \multicolumn{4}{|l|}{ Mother's education } \\
\hline Vocational $^{2}(\%)$ & 9.5 & 13.2 & 11.2 \\
\hline Secondary $^{3}(\%)$ & 54.0 & 41.5 & 48.3 \\
\hline Higher $^{4}(\%)$ & 36.5 & 45.3 & 40.5 \\
\hline \multicolumn{4}{|l|}{ Father's education } \\
\hline Vocational $^{2}(\%)$ & 31.7 & 31.4 & 31.6 \\
\hline Secondary ${ }^{3}(\%)$ & 39.7 & 39.2 & 39.5 \\
\hline Higher $^{4}(\%)$ & 28.6 & 29.4 & 28.9 \\
\hline \multicolumn{4}{|l|}{ Family } \\
\hline Two-parent (\%) & 92.1 & 90.9 & 91.5 \\
\hline One-parent (\%) & 7.9 & 9.1 & 8.5 \\
\hline \multicolumn{4}{|l|}{$\begin{array}{l}\text { Number of children } \\
\text { in the family }\end{array}$} \\
\hline One (\%) & 31.7 & 29.1 & 30.5 \\
\hline Two (\%) & 49.2 & 52.7 & 50.8 \\
\hline Three (\%) & 14.3 & 16.4 & 15.3 \\
\hline Four (\%) & 3.2 & 1.8 & 2.5 \\
\hline $\operatorname{Six}(\%)$ & 1.6 & 0.0 & 0.8 \\
\hline \multicolumn{4}{|l|}{$\begin{array}{l}\text { The sequence of the } \\
\text { child in the family }\end{array}$} \\
\hline First (\%) & 64.5 & 63.6 & 64.1 \\
\hline Second (\%) & 22.6 & 29.1 & 25.6 \\
\hline Third (\%) & 9.7 & 7.3 & 8.5 \\
\hline Fourth (\%) & 1.6 & 0.0 & 0.9 \\
\hline Sixth (\%) & 1.6 & 0.0 & 0.9 \\
\hline
\end{tabular}

${ }^{1}$ Mean \pm standard deviation.

${ }^{2}$ Eight years of primary school followed by three years of vocational school. ${ }^{3}$ Eight years of primary school followed by four years of secondary school.

${ }^{4}$ Eight years of primary school, four years of secondary school and three to five years of studies ending in receiving bachelor's or master's degree.

girls. It is also important to note that total fat density was higher in boys, whereas total carbohydrates density and available carbohydrates density were higher in girls, although these findings did not reach statistical significance (P: 0.057, 0.073 and 0.080 , respectively).
Table 4 presents the percentages of the studied 6-yearold children in the reference ranges for macronutrient intake. No statistically significant differences between girls and boys were observed. However, it is noteworthy that almost all of the studied children exceeded the recommended intake of energy from saturated fatty acids and almost all of them had intakes of energy from polyunsaturated fatty acids below the recommendations.

\section{Discussion}

\section{Summary of the studies selected for comparison of} dietary intake

As it was stated in the Introduction, no publications on dietary intakes of only 6-year-old children were found in the literature published after the year 2000. Therefore, to compare the results, studies which included 6-yearolds or children of approximate age were searched for. The bases which were searched included: EBSCOhost, PubMed, ScienceDirect. Also reports of national surveys published on the government websites of the United Kingdom [31] and the United States [32] were used. The summary of these studies is showed in Additional file 1: Table S1. This summary shows that the age groups which were the most similar to the age of the studied children were: the population of Spanish 6-7-year-olds $[12,13]$, Cretan children aged 6.8 years [11] and 7 -yearold English children [33]. In six out of twelve studies, the method of food record was applied: estimation using household measures was used in five studies [8-11,15,33] and weighed food record was used in one study [7]. The studies most frequently covered one day of intake (five out of twelve studies) [6,14-16,34]. All of the studies included intake of energy, however, in terms of nutrients which were analysed, the studies were diverse. Only in two studies $[9,13]$, the percentages of children below, above or within the recommendations were presented.

\section{Energy intake}

Energy intake was adequate in most of the studied 6year-olds which was reflected in the highest percentage of children with healthy weight. Although the percentages of underweight and obese children were low, there was a substantial percentage of overweight children. It is highly unfavourable because in overweight children the risk of being overweight or becoming obese later in life

Table 2 Energy intake in the studied 6-year-old children according to the percentile categories for BMI

\begin{tabular}{|c|c|c|c|c|c|c|}
\hline \multirow[t]{2}{*}{ Percentile categories for BMI } & \multicolumn{4}{|c|}{ Energy intake (kcal) } & \multicolumn{2}{|c|}{ Population } \\
\hline & Mean & SD & Median & SE & $\%$ & $\mathrm{n}$ \\
\hline Below the $5^{\text {th }}$ percentile (underweight) & 1696 & 188 & 1726 & 94 & 3.3 & 4 \\
\hline $5^{\text {th }}-84^{\text {th }}$ percentile (healthy weight) & 1820 & 314 & 1801 & 35 & 68.3 & 82 \\
\hline $85^{\text {th }}-94^{\text {th }}$ percentile (overweight) & 1942 & 354 & 1954 & 68 & 22.6 & 27 \\
\hline $95^{\text {th }}$ percentile and above (obesity) & 1763 & 237 & 1650 & 90 & 5.8 & 7 \\
\hline
\end{tabular}


Table 3 Energy and macronutrient intakes in the studied 6-year-old children

\begin{tabular}{|c|c|c|c|c|c|c|c|c|c|c|c|c|c|c|}
\hline \multirow[t]{2}{*}{ Energy/nutrient } & \multirow[t]{2}{*}{$\begin{array}{l}\text { Reference } \\
\text { values }\end{array}$} & \multicolumn{2}{|c|}{$\begin{array}{c}\text { Girls } \\
(n=64)\end{array}$} & \multicolumn{2}{|c|}{$\begin{array}{c}\text { Boys } \\
(n=56)\end{array}$} & \multicolumn{2}{|c|}{$\begin{array}{l}\text { All children } \\
(n=120)\end{array}$} & \multirow[t]{2}{*}{$P$} & \multicolumn{2}{|c|}{$\begin{array}{c}\text { Girls } \\
(n=64)\end{array}$} & \multicolumn{2}{|c|}{$\begin{array}{c}\text { Boys } \\
(n=56)\end{array}$} & \multicolumn{2}{|c|}{$\begin{array}{c}\text { All children } \\
(n=120)\end{array}$} \\
\hline & & Mean & SD & Mean & SD & Mean & SD & & Median & $\mathrm{SE}$ & Median & SE & Median & SE \\
\hline \multicolumn{15}{|l|}{ Energy } \\
\hline (kcal) & \multirow{2}{*}{$\begin{array}{l}\text { body weight } \\
\text { dependent }\end{array}$} & 1781 & 310 & 1907 & 318 & 1840 & 319 & 0.035 & 1746 & 39 & 1863 & 43 & 1812 & 29 \\
\hline$(k J)$ & & 7462 & 1298 & 7986 & 1332 & 7707 & 1335 & 0.034 & 7313 & 162 & 7809 & 178 & 7589 & 122 \\
\hline \multicolumn{15}{|l|}{ Total protein } \\
\hline (g) & $\begin{array}{l}\text { body weight } \\
\text { dependent }\end{array}$ & 59.1 & 10.8 & 62.6 & 12.1 & 60.7 & 11.5 & 0.145 & 57.1 & 1.3 & 60.5 & 1.6 & 58.4 & 1.1 \\
\hline (g/kg body weight) & $0.84^{1}$ & 2.6 & 0.6 & 2.7 & 0.5 & 2.7 & 0.6 & 0.758 & 2.5 & 0.8 & 2.7 & 0.7 & 2.6 & 0.5 \\
\hline (\% of energy) & $10-15 \%$ & 13.4 & 1.8 & 13.3 & 1.7 & 13.4 & 1.7 & 0.935 & 13.0 & 0.2 & 13.7 & 0.2 & 13.2 & 0.2 \\
\hline (g/1000 kcal) & NA & 33.4 & 4.4 & 32.9 & 4.2 & 33.2 & 4.3 & 0.908 & 32.3 & 0.5 & 33.9 & 0.6 & 32.8 & 0.4 \\
\hline \multicolumn{15}{|l|}{ Animal protein } \\
\hline (g) & NA & 40.1 & 9.4 & 41.7 & 10.5 & 40.8 & 9.9 & 0.386 & 38.9 & 1.2 & 40.9 & 1.4 & 39.3 & 0.9 \\
\hline (\% of total protein) & NA & 67.4 & 5.3 & 66.0 & 6.3 & 66.7 & 5.8 & 0.538 & 68.1 & 0.7 & 68.0 & 0.8 & 68.1 & 0.5 \\
\hline (g/1000 kcal) & NA & 22.7 & 4.6 & 22.0 & 4.5 & 22.3 & 4.6 & 0.929 & 22.1 & 0.6 & 22.8 & 0.6 & 22.3 & 0.4 \\
\hline \multicolumn{15}{|l|}{ Plant protein } \\
\hline (g) & NA & 19.0 & 3.2 & 20.9 & 3.7 & 19.9 & 3.6 & 0.003 & 18.9 & 0.4 & 20.5 & 0.5 & 19.6 & 0.3 \\
\hline (\% of total protein) & NA & 32.6 & 5.3 & 34.0 & 6.3 & 33.3 & 5.8 & 0.538 & 31.9 & 0.6 & 32.0 & 0.8 & 31.9 & 0.5 \\
\hline (g/1000 kcal) & NA & 10.7 & 1.0 & 11.0 & 1.2 & 10.8 & 1.1 & 0.183 & 10.7 & 0.1 & 11.0 & 0.2 & 10.8 & 0.1 \\
\hline \multicolumn{15}{|l|}{ Total fat } \\
\hline (g) & NA & 64.7 & 13.7 & 72.2 & 18.2 & 68.2 & 16.3 & 0.026 & 64.5 & 1.7 & 69.0 & 2.4 & 66.1 & 1.5 \\
\hline (\% of energy) & $20-30 \%$ & 32.2 & 4.1 & 33.3 & 3.8 & 32.7 & 4.0 & 0.062 & 32.2 & 0.5 & 33.5 & 0.5 & 32.7 & 0.4 \\
\hline (g/1000 kcal) & NA & 36.3 & 4.6 & 37.6 & 4.3 & 36.9 & 4.5 & 0.057 & 36.3 & 0.6 & 37.9 & 0.6 & 37.0 & 0.4 \\
\hline \multicolumn{15}{|l|}{ Saturated fatty acids } \\
\hline (g) & NA & 27.87 & 6.82 & 31.98 & 9.14 & 29.79 & 8.21 & 0.006 & 27.89 & 0.85 & 30.64 & 1.22 & 29.13 & 0.75 \\
\hline (\% of energy) & $<10 \%$ & 14.1 & 2.3 & 14.9 & 2.3 & 14.5 & 2.3 & 0.038 & 14.0 & 0.3 & 14.6 & 0.3 & 14.4 & 0.2 \\
\hline (g/1000 kcal) & NA & 15.62 & 2.50 & 16.59 & 2.54 & 16.07 & 2.56 & 0.038 & 15.56 & 0.31 & 16.21 & 0.34 & 16.05 & 0.23 \\
\hline \multicolumn{15}{|l|}{$\begin{array}{l}\text { Polyunsaturated } \\
\text { fatty acids }\end{array}$} \\
\hline (g) & NA & 8.15 & 3.11 & 8.40 & 2.58 & 8.26 & 2.87 & 0.474 & 7.71 & 0.39 & 7.91 & 0.34 & 7.87 & 0.26 \\
\hline (\% of energy) & $6-10 \%$ & 4.2 & 1.7 & 4.0 & 1.1 & 4.1 & 1.4 & 0.846 & 3.8 & 0.2 & 3.7 & 0.1 & 3.8 & 0.1 \\
\hline (g/1000 kcal) & NA & 4.62 & 1.88 & 4.41 & 1.21 & 4.52 & 1.60 & 0.842 & 4.24 & 0.23 & 4.16 & 0.16 & 4.22 & 0.15 \\
\hline \multicolumn{15}{|c|}{ Monounsaturated fatty acids } \\
\hline (g) & NA & 23.98 & 5.34 & 26.94 & 7.17 & 25.36 & 6.41 & 0.039 & 23.94 & 0.67 & 25.13 & 0.96 & 24.38 & 0.58 \\
\hline (\% of energy) & $>10 \%^{2}$ & 12.1 & 1.7 & 12.6 & 1.8 & 12.3 & 1.8 & 0.108 & 12.1 & 0.2 & 12.4 & 0.2 & 12.2 & 0.2 \\
\hline (g/1000 kcal) & NA & 13.45 & 1.85 & 14.03 & 2.05 & 13.72 & 1.96 & 0.108 & 13.46 & 0.23 & 13.81 & 0.27 & 13.57 & 0.18 \\
\hline \multicolumn{15}{|l|}{ Cholesterol } \\
\hline (mg) & $<300$ & 269 & 85 & 277 & 83 & 273 & 84 & 0.474 & 244 & 11 & 260 & 11 & 257 & 8 \\
\hline (g/1000 kcal) & NA & 151 & 41 & 145 & 33 & 148 & 37 & 0.621 & 141 & 5 & 137 & 4 & 140 & 3 \\
\hline \multicolumn{15}{|l|}{ Total carbohydrates } \\
\hline (g) & NA & 254.2 & 49.1 & 266.0 & 41.1 & 259.7 & 45.7 & 0.160 & 249.9 & 6.1 & 259.6 & 5.5 & 255.7 & 4.2 \\
\hline (g/1000 kcal) & NA & 142.5 & 11.8 & 140.1 & 11.0 & 141.4 & 11.5 & 0.073 & 141.6 & 1.5 & 138.5 & 1.5 & 140.1 & 1.0 \\
\hline
\end{tabular}


Table 3 Energy and macronutrient intakes in the studied 6-year-old children (Continued)

\begin{tabular}{|c|c|c|c|c|c|c|c|c|c|c|c|c|c|c|}
\hline \multicolumn{15}{|c|}{ Available carbohydrates } \\
\hline (g) & $130^{3}$ & 239.1 & 47.0 & 250.0 & 38.8 & 244.2 & 43.6 & 0.170 & 233.1 & 5.9 & 243.8 & 5.2 & 240.9 & 4.0 \\
\hline (\% of energy) & $55-70 \%{ }^{4}$ & 53.6 & 4.6 & 52.7 & 4.1 & 53.2 & 4.4 & 0.084 & 53.3 & 0.6 & 52.3 & 0.6 & 52.7 & 0.4 \\
\hline (g/1000 kcal) & NA & 134.0 & 11.5 & 131.6 & 10.3 & 132.9 & 11.0 & 0.080 & 133.3 & 1.4 & 130.8 & 1.4 & 131.8 & 1.0 \\
\hline \multicolumn{15}{|l|}{ Lactose } \\
\hline (g) & NA & 17.1 & 7.4 & 17.3 & 7.3 & 17.2 & 7.3 & 0.975 & 16.5 & 0.9 & 15.3 & 1.0 & 15.9 & 0.7 \\
\hline (\% of energy) & NA & 3.9 & 1.6 & 3.6 & 1.4 & 3.7 & 1.5 & 0.420 & 3.9 & 0.2 & 3.6 & 0.2 & 3.6 & 0.1 \\
\hline (g/1000 kcal) & NA & 9.6 & 4.0 & 9.1 & 3.5 & 9.4 & 3.8 & 0.420 & 9.7 & 0.5 & 8.9 & 0.5 & 9.1 & 0.3 \\
\hline \multicolumn{15}{|l|}{ Sucrose } \\
\hline (g) & NA & 83.8 & 25.9 & 82.5 & 19.6 & 83.2 & 23.1 & 0.770 & 81.1 & 3.2 & 82.8 & 2.6 & 82.2 & 2.1 \\
\hline (\% of energy) & NA & 18.6 & 4.1 & 17.4 & 3.5 & 18.0 & 3.9 & 0.035 & 18.7 & 0.5 & 17.5 & 0.5 & 18.2 & 0.4 \\
\hline \multicolumn{15}{|l|}{ Starch } \\
\hline (g) & NA & 111.1 & 20.2 & 124.7 & 21.9 & 117.5 & 22.0 & 0.001 & 108.2 & 2.5 & 126.4 & 2.9 & 114.5 & 2.0 \\
\hline (\% of energy) & NA & 25.1 & 3.0 & 26.3 & 3.0 & 25.6 & 3.0 & 0.030 & 24.6 & 0.4 & 26.0 & 0.4 & 25.3 & 0.3 \\
\hline (g/1000 kcal) & NA & 62.7 & 7.4 & 65.7 & 7.5 & 64.1 & 7.6 & 0.030 & 61.5 & 0.9 & 65.1 & 1.0 & 63.3 & 0.7 \\
\hline \multicolumn{15}{|l|}{ Dietary fibre } \\
\hline (g) & $14^{5}$ & 15.2 & 3.0 & 16.0 & 3.6 & 15.6 & 3.3 & 0.166 & 15.1 & 0.4 & 15.8 & 0.5 & 15.2 & 0.3 \\
\hline (g/1000 kcal) & NA & 8.6 & 1.2 & 8.5 & 1.7 & 8.5 & 1.5 & 0.293 & 8.4 & 0.2 & 8.1 & 0.2 & 8.4 & 0.1 \\
\hline \multicolumn{15}{|l|}{ Total water } \\
\hline (g) & $1600^{5}$ & 1478 & 235 & 1506 & 231 & 1491 & 233 & 0.515 & 1463 & 29 & 1492 & 31 & 1470 & 21 \\
\hline (g/1000 kcal) & NA & 838 & 106 & 799 & 113 & 819 & 111 & 0.034 & 831 & 13 & 774 & 15 & 815 & 10 \\
\hline
\end{tabular}

$P$ - significance; NA - not available; NS - not significant $(P>0.05)$.

${ }^{1}$ EAR.

${ }^{2}$ Calculated by difference as: total fat - (saturated fatty acids + polyunsaturated fatty acids).

${ }^{3} \mathrm{RDA}$.

${ }^{4}$ Calculated by difference: as the percentage of total energy - energy from total protein - energy from total fat.

${ }^{5} \mathrm{Al}$.

is higher than in normal-weight children [35]. It is interesting that energy intake increased through all of the percentile categories, except for obesity. The relatively low energy intake observed in obese children is most probably due to underreporting of food intake by their parents. Although underreporting is little explored in children aged 6 years or less, it is well known that the rate of underreporting is higher in overweight subjects, compared to non-overweight, and the highest in the obese [36-39]. In the current study, the probability of underreporting by the preschool staff, who recorded children's food intake during the stay in the preschool, is very low because of the high motivation and involvement of the staff along with the supervision of the author of the article.

The observed higher energy intake in boys is consistent with the results of the previous studies which reported significantly higher energy intake in boys compared to girls of various age and from various countries: in 4-5.6-yearolds from Belgium [9], in 7-year-olds from England [33], in 5-11-year-olds from France [15], in 4-5-year-olds from Greece [40] and in 7-9-year-olds from Portugal [34] and in 4-5-year-olds from Vietnam [41].

\section{Macronutrient intake}

Protein

In comparison to the previously studied children, intake of energy from protein in the studied 6-year-olds was lower than in Belgian 4.5-6-year-olds [9], French 5-11-year-olds [15] and Greek children [11,40], and much lower than in Spanish 6-7-year-olds [12,13], Spanish 6-9-year-olds [14], Portuguese 7-9-year-olds [34] and Vietnamese 4-5-year-olds [41]. However, it was higher than in British [7] and Polish [6] 4-6-yearolds, and similar to energy from protein in the diets of American children aged 6-11 years and less than 6 years [16]. Intake of protein per $\mathrm{kg}$ of body weight in the studied 6-year-olds was lower than in Belgian 4.56 -year-olds [10] and protein density was lower than in Cretan children [11].

Total protein intake in the studied 6-year-olds poses little risk of deficiency. However, there were substantial percentages of girls and boys whose intake of energy from total protein was above the recommended. Nevertheless, these percentages were much lower than in Belgian 4.5-6year-olds (50.0\% of girls and $56.5 \%$ of boys) [9]. 
Table 4 The percentages of the studied 6-year-old children in the reference ranges for macronutrient intake

\begin{tabular}{|c|c|c|c|c|}
\hline Nutrient & $\begin{array}{c}\text { Girls }(n=64) \\
\%\end{array}$ & $\begin{array}{c}\text { Boys }(n=56) \\
\%\end{array}$ & $\begin{array}{l}\text { All children }(n=120) \\
\%\end{array}$ & $P$ \\
\hline \multicolumn{5}{|l|}{ Total protein (\% of energy) } \\
\hline Below the recommendations & 0.0 & 3.6 & 1.7 & \multirow{3}{*}{0.30} \\
\hline Within the recommendations & 84.4 & 80.4 & 82.5 & \\
\hline Above the recommendations & 15.6 & 16.1 & 15.8 & \\
\hline \multicolumn{5}{|l|}{ Total fat (\% of energy) } \\
\hline Within the recommendations & 26.6 & 23.2 & 25.0 & \multirow{2}{*}{0.673} \\
\hline Above the recommendations & 73.4 & 76.8 & 75.0 & \\
\hline \multicolumn{5}{|c|}{ Saturated fatty acids (\% of energy) } \\
\hline Within the recommendations & 3.1 & 0.0 & 1.7 & \multirow{2}{*}{0.182} \\
\hline Above the recommendations & 96.9 & 100.0 & 98.3 & \\
\hline \multicolumn{5}{|c|}{ Polyunsaturated fatty acids (\% of energy) } \\
\hline Below the recommendations & 93.8 & 96.4 & 95.0 & \multirow{3}{*}{0.61} \\
\hline Within the recommendations & 4.7 & 3.6 & 4.2 & \\
\hline Above the recommendations & 1.6 & 0.0 & 0.8 & \\
\hline \multicolumn{5}{|c|}{ Monounsaturated fatty acids (\% of energy) } \\
\hline Below the recommendations & 7.8 & 5.4 & 6.7 & \multirow{2}{*}{0.59} \\
\hline Within the recommendations & 92.2 & 94.6 & 93.3 & \\
\hline \multicolumn{5}{|l|}{ Cholesterol (mg) } \\
\hline Within the recommendations & 71.9 & 71.4 & 71.7 & \multirow{2}{*}{0.95} \\
\hline Above the recommendations & 28.1 & 28.6 & 28.3 & \\
\hline \multicolumn{5}{|c|}{ Available carbohydrates (\% of energy) } \\
\hline Below the recommendations & 60.9 & 69.6 & 65.0 & \multirow{2}{*}{0.31} \\
\hline Within the recommendations & 39.1 & 30.4 & 35.0 & \\
\hline \multicolumn{5}{|l|}{ Dietary fibre (g) } \\
\hline Below the recommendations & 34.4 & 32.1 & 33.3 & \multirow{2}{*}{0.796} \\
\hline Within the recommendations & 65.6 & 67.9 & 66.7 & \\
\hline \multicolumn{5}{|l|}{ Total water (g) } \\
\hline Below the recommendations & 70.3 & 69.6 & 70.0 & \multirow{2}{*}{0.936} \\
\hline Within the recommendations & 29.7 & 30.4 & 30.0 & \\
\hline
\end{tabular}

$P$ - significance.

Intake of animal protein (\% of total protein) in the studied 6-year-olds was similar to that observed in the previously studied Polish 4-6-year-olds [6], Belgian 46.5-year-olds [10] and Vietnamese 4-5-year-olds [41]. It is recommended to reduce the intake of animal protein since its high intake is related to an increased diabetes risk [42], as well as to earlier pubertal onset which may contribute to a higher risk of breast cancer [43]. Moreover, it causes reduced intake of plant protein which is inversely related to the risk of ischaemic heart disease [44]. It is surprising that although the studied children attended preschools promoting health, their intake of total, animal and plant protein did not differ much from the intakes observed in other children.
Fat

Total fat intake in the studied 6-year-olds exceeded the recommendations and should be lowered. Former concerns that lowering energy from fat in children's diets may cause decreased intakes and deficiencies of essential nutrients, and thus poor growth [45], have been dispelled by the results of many intervention and longitudinal studies on children of various age [46-49]. On the contrary, it is emphasised that energy from fat in children's diets should not exceed 30\% because of the benefits to lipid profile $[47,50]$ as well as reduced risk of cardiovascular diseases and cancer, not only in the short term but also in adulthood [51].

Although the studied 6-year-olds exceeded the recommendations on fat intake, energy from fat was the lowest 
compared to children from other European countries: France [15], Great Britain [7,8,33], Greece [11,40], Portugal [34] and Spain [12-14]. It is important to note that intake of energy from fat was the highest in Greek children [40] and Cretan children [11], as well as Spanish 6-7-year-olds [12,13], reaching $40 \%$ and more energy from this macronutrient. Only in Belgian 4-6.5-year-olds [9] and Polish 4-6-year-olds [6], intake of energy from fat was lower than in the studied 6-year-olds, but only Belgian children met the recommendations [9]. In comparison to children from outside Europe, intake of energy from fat in the studied children was similar to the intake observed in American children aged 6-11 years and less than 6 years [16], but it was much lower than in Vietnamese 4-5-year-olds [41].

The structure of fatty acid intake was also unfavourable. It was characterised by excessive intake of saturated fatty acids, higher even than monounsaturated fatty acid intake, along with inadequate intake of polyunsaturated fatty acids. It is especially disconcerting in case of boys, since it is well recognised that males are at higher risk for atherosclerosis than females and the studied boys' intakes of both total fat and saturated fatty acids (g, \% of energy, g/1000 kcal) were significantly higher in comparison to girls. Moreover, inadequate intake of polyunsaturated fatty acids observed in almost all of the studied 6-year-olds may have adverse effect on their neurodevelopment [52].

Intakes of fatty acids in children of various age from other countries were usually similar to those observed in the current study. Excessive intake of energy from saturated fatty acids was observed also in the diets of children in Belgium [9], France [15], Great Britain [7,8,33], Greece [11,40], Portugal [34], Spain [12,14] and the United States [16], as well as in the previously studied Polish children [6]. Intake of energy from polyunsaturated fatty acids was lower than the recommended also in the diets of Belgian 4-6.5-year-olds [9], British children [8,33], Cretan children [11], Polish 4-6-year-olds [6], Portuguese 7-9-year-olds [34] and Spanish 6-9-year-olds [14], and adequate only in the diets of Spanish 6-7-yearolds [12]. Intake of energy from monounsaturated fatty acids in the studied 6-year-olds was much lower than in Cretan children [11], Spanish 6-7-year-olds [12] and Spanish 6-9-year-olds [14], lower than in Polish 4-6year-olds [6] and Portuguese 7-9-year-olds [34], similar to British children [8,33], but higher than in Belgian 46.5-year-olds [9]. Nutrient densities of fatty acids in the studied children's diets were lower than in Cretan children [11], especially for saturated and monounsaturated fatty acids.

Although cholesterol intake in the studied 6-year-olds was in accordance with the recommendations, it was higher than in American children aged 6-11-years and less than 6 years [16] and in Polish 4-6-year-olds [6], and much higher than in Belgian 4-6.5-year-olds [9]. However, it was lower than in Spanish 6-7-year-olds [12] and Spanish 6-9-year-olds [14] who exceeded the recommendations. Cholesterol density was higher than in Cretan children [11], but lower than in Spanish 6-7year-olds [12].

Despite not exceeding the recommendations on cholesterol intake by the studied children, density of this nutrient, along with the adverse structure of fatty acid intake, need urgent intervention. Otherwise, unfavourable structure of fatty acid intake will soon be accompanied by excessive cholesterol intake due to the inevitable increase of energy intake as children grow. It is surprising that although the children attended preschools aimed at promoting health, their intakes of energy from fat and fatty acids were so unfavourable. These findings confirm unfavourable food habits observed in the previous studies on Polish preschoolers [53,54]. Moreover, these findings are similar to those obtained in other populations of children in Europe and show the need to work out a common educational programme to improve nutrition in young European children taking into account food habits which are specific to the tradition or food supply of each country.

\section{Carbohydrates}

Intake of available carbohydrates in the studied 6-yearolds was below the recommended. However, it is worth noting that carbohydrate content of foods in Polish food composition tables [20] was calculated by difference, that is by subtracting the content of moisture, protein, fat, ash and alcohol from the total weight of the food [21]. Intake of carbohydrates was reported to be $14 \%$ higher when measured by difference compared to carbohydrates measured directly (direct analysis of carbohydrate components and summation to obtain a total carbohydrate value) [21]. Therefore, it is probable that intake of carbohydrates in the studied 6-year-olds was in fact even more below the recommendations than it can be observed from the obtained results.

Due to the differences in methodology, it is difficult to compare the results with the results of other studies. For sure, intake of energy from carbohydrates in the studied 6-year-olds was lower than in Polish 4-6-year-old children studied by Szponar et al. [6] who used the same method of carbohydrate determination. In comparison to British 4-6-year-olds [7], British 4-10-year-olds [8], British 7-year-olds [33] and French 5-11-year-olds [15], intake of energy from carbohydrate in the studied 6-year-olds was higher. However, the aforementioned studies on British and French children used McCance and Widdowson's 'The Composition of Foods' in which carbohydrate content was obtained by direct analysis 
[21]. Therefore, if in case of French 5-11-year-olds [15] the difference in energy from carbohydrates is $11.3 \%$ compared to the studied 6-year-olds, the observed difference is mainly due to different methodology and so the intake is similar. And if in case of British children this difference is from $2.3 \%$ [8] to $4.0 \%$ [33], it is probable that the intake of energy from carbohydrates by the studied 6-year-olds was in fact lower than in British children. Surely, intake of energy from carbohydrates in the studied 6-year-olds was lower than in Belgian 4-6.5year-olds [9] whose intake was $54.87 \%$ in girls and $54.19 \%$ in boys and was determined using McCance and Widdowson's The Composition of Foods. The lowest intake of energy from carbohydrates was reported in Spanish 6-7-year-olds [12,13], only $38.3 \%$, however, the method of carbohydrate determination in Spanish food composition tables was not available to the author.

Intake of sucrose in the studied 6-year-olds seems to be high. It is recommended to reduce intake of all monosaccharides and disaccharides, that is also sucrose, added to foods by the manufacturer, cook or consumer, as well as sugars naturally present in honey, syrups and fruit juices to less than $10 \%$ of energy [25]. In the studied 6-yearolds the intake of energy only from sucrose was almost twice higher than the WHO recommendations for all added monosaccharides and disaccharides. These findings reflect the adverse habit of adding a lot of sugar to tea and other beverages, which is very popular in the studied region, as well as the adverse habit of snacking on sweets between the main meals. A study on Polish 5-6-year-olds showed that more than $50 \%$ of the children snacked on sweets twice or more times a day [53]. Besides, it is well recognised that preferences for sweet taste are innate and typical of infants and young children irrespective of gender $[55,56]$ and probably this was also an important factor of high intake of sucrose in the studied 6-year-olds.

High intake of sucrose in the studied 6-year-olds is very unfavourable. The studies showed that an increase in sucrose intake increases triacylglycerol concentration [57] which is the risk factor for atherosclerosis. Moreover, high intake of added sugars in children is associated with lower intakes of micronutrients [58-61] and with lower intakes of important food groups such as grains, vegetables, fruits, and dairy $[58,60,61]$. Most of the staff who worked in the studied preschools and most of the studied children's parents knew that high sucrose intake increases dental caries $[62,63]$ and that sugar intake should be limited because it does not provide any additional nutrients in children's diets $[64,65]$. Therefore, it is surprising to find high sucrose intake in children who attended preschools aimed at promoting health. Most probably food habits were stronger than knowledge.

It is interesting that intake of sucrose (\% of energy, $\mathrm{g} / 1000 \mathrm{kcal}$ ) in the studied girls was significantly higher than in boys. This seems to reflect female higher preferences for sweet taste which are typical in teenagers and adult women [66-68].

In other studies, intake of sucrose was not analysed. In British 4-10-year-old children [8] and British 7-year-olds [33], intake of non-milk extrinsic sugars was reported to exceed the recommendations. In the study on Belgian 4-6.5-year-olds [9], Spanish 6-7-year-olds [12,13] and Portuguese 7-9-year-olds [34], intake of energy from simple carbohydrates was reported to be high, however, only Moreira et al. [34] defined the term 'simple carbohydrates' as all monosaccharides and disaccharides added to foods by the manufacturer, cook or consumer, as well as sugars naturally present in honey, syrups and fruit juices.

No recommendations on starch intake are available. Intake of energy from this macronutrient in the studied 6-year-olds was similar to that reported in British 7-yearolds [33] and slightly lower than in British 4-10-year-olds [8]. In other studies, intake of energy from complex carbohydrates was reported. In French 5-11-year-olds [15], it was similar to intake of energy from starch in the studied 6-year-olds, whereas it was slightly lower in Belgian 4-6.5year-olds [9]. Very low intake of energy from complex carbohydrates was found in Spanish 6-7-year-olds, only $17.8 \%$ [13].

Dietary fibre intake in most of the studied 6-year-olds was in accordance with the recommendations and was similar to the intake reported in Polish 4-6-year-olds [6], in Belgian 4-6.5-year-olds [9] and in Spanish 6-9-year-olds [14] but it was lower than in Spanish 6-7-year-olds [13] and Portuguese 7-9-year-olds [34]. Dietary fibre density in the studied children's diets was higher than in Cretan children [11] but similar to dietary fibre density in the diets of Belgian 4-6.5-year-olds [9]. In British 4-10-year-olds [8] and British 7-year-olds [33], intake of non-starch polysaccharides was analysed so the comparison is not possible.

\section{Water}

There is a concern that total water intake in the studied 6-year-olds may be inadequate. Low intake of water is unfavourable since water is not only essential for day-today health [69] but may also play a role in the prevention of chronic diseases [70]. It is probable that parents underestimated the role of this macronutrient because they often hear in the Polish mass media about the importance of protein, vitamins or minerals to the health of their children, but rarely attention is drawn to the importance of water. However, it cannot be excluded that some parents forgot about reporting their children's water intake despite having been asked by the author to do so. It is also possible that preschool staff failed to fully control the children who had access to water during preschool hours. Despite the fact that the author and the preschool staff asked the children to inform the 
teacher each time they would like to drink water, it is possible that not all children remembered about it.

Water intake was analysed only in one study on Belgian 4-6.5-year-olds [9] and was reported to be low. Also in the studies on older children and adolescents, information on water intake was provided by only a few studies [71]. This issue needs further studies, since providing information on water intake in children is of great importance to public health and to working out nutritional education programmes for the societies.

\section{Conclusions}

In conclusion, many adverse characteristics of the children's diets were observed, mainly the excessive intake of total fat, saturated fatty acids and sucrose, along with inadequate intake of polyunsaturated fatty acids, available carbohydrates, and starch. These tendencies are common to the diets of children of similar age in other European countries and show the need to work out a common educational programme to improve nutrition in young European children taking into account food habits which are specific to the tradition or food supply of each country. From the public health point of view, it is important to provide the lacking information about the intake of animal and plant protein, as well as about water intake in young children in Europe.

\section{Additional file}

Additional file 1: Table S1. The summary of the studies on dietary intake, which included 6-year-olds or children of approximate age, used in the section Discussion (studies showed in alphabetical order of the country).

\section{Competing interests}

The author declares that she has no competing interests. Financial support was received from the Polish Ministry of Science and Higher Education.

\section{Acknowledgements}

I would like to thank Professor Wojciech Chalcarz for all his valuable comments during the preparation of this article.

Received: 18 March 2014 Accepted: 28 July 2014

Published: 3 August 2014

\section{References}

1. Merkiel S, Chalcarz W: Nutrition in preschool age: Part 1. Importance, reference values, methods of research and their application. Review. New Med (Wars) 2007, 11:68-73.

2. Institute for Health Metrics and Evaluation: Global Burden of Disease (GBD) Arrow Diagram. [http://www.healthmetricsandevaluation.org/gbd/ visualizations/gbd-arrow-diagram]

3. Antoszczuk G: Edukacja zdrowotna najmłodszych - dzieci w wieku przedszkolnym w programie promocji zdrowia, in Polish. (Health education of young children - preschool children in the health education programme.). Zdrowie Publ 2002, 112(Supl 1):17-19.

4. Krawczyński M: Norma kliniczna w pediatrii, in Polish. (Clinical norm in paediatrics). Warszawa: Wydawnictwo Lekarskie PZWL; 2005

5. Sochacka-Tatara E, Jacek R, Sowa A, Musiał A: Ocena sposobu żywienia dzieci w wieku przedszkolnym, in Polish. (Assessment of preschool children's diet.). Probl Hig Epidemiol 2008, 89:389-394.
6. Szponar L, Sekuła W, Rychlik E, Ołtarzewski M, Figurska K: Badania indywidualnego spożycia żywności i stanu odżywienia w gospodarstwach domowych, in Polish. (Research on individual food intake and nutritional status in households.). Warszawa: Instytut Żywności i Żywienia; 2003.

7. Great Britain Office for National Statistics Social Survey Division: National Diet and Nutrition Survey: young people aged 4 to 18 years. Volume 1: Report of the diet and nutrition survey. London: Stationery Office; 2000.

8. Bates B, Lennox A, Prentice A, Bates C, Swan G: National Diet and Nutrition Survey; Headline results from Years 1, 2 and 3 (combined) of the Rolling Programme (2008/2009 - 2010/11). [https://www.gov.uk/government/ publications/national-diet-and-nutrition-survey-headline-results-from-years-12-and-3-combined-of-the-rolling-programme-200809-201011]

9. Huybrechts I, De Henauw S: Energy and nutrient intakes by pre-school children in Flanders-Belgium. Br J Nutr 2007, 98:600-610.

10. Lin Y, Bolca S, Vandevijvere S, Van Oyen H, Van Camp J, De Backer G, Foo $\mathrm{LH}$, De Henauw S, Huybrechts I: Dietary sources of animal and plant protein intake among Flemish preschool children and the association with socio-economic and lifestyle-related factors. Nutr J 2011, 10:97.

11. Smpokos EA, Linardakis M, Papadaki A, Theodorou AS, Havenetidis K, Kafatos A: Differences in energy and nutrient-intake among Greek children between 1992/93 and 2006/07. J Hum Nutr Diet 2013, doi:10.1111/jhn.12122.

12. Rodríguez-Artalejo F, Garcés C, Gorgojo L, López García E, Martín Moreno JM, Benavente M, del Barrio JL, Rubio R, Ortega H, Fernández O, de Oya M: Dietary patterns among children aged 6-7 y in four Spanish cities with widely differing cardiovascular mortality. Eur J Clin Nutr 2002, 56:141-148.

13. Royo-Bordonada MA, Gorgojo L, Martín Moreno JM, Garcés C, Rodríguez-Artalejo F, Benavente M, Mangas A, de Oya M: Spanish children's diet: compliance with nutrient and food intake guidelines. Eur J Clin Nutr 2003, 57:930-939.

14. Serra-Majem L, Ribas-Barba L, Pérez-Rodrigo C, Aranceta Bartrina J: Nutrient adequacy in Spanish children and adolescents. Br J Nutr 2006, 96(Suppl 1):S49-S57.

15. Maillard G, Charles MA, Lafay L, Thibult N, Vray M, Borys JM, Basdevant A, Eschwège $E$, Romon $M$ : Macronutrient energy intake and adiposity in non obese prepubertal children aged 5-11 y (the Fleurbaix Laventie Ville Santé Study). Int J Obes 2000, 24:1608-1617.

16. Wright JD, Wang CY, Kennedy-Stephenson J, Ervin RB: Dietary intake of ten key nutrients for public health, United States: 1999-2000. Advance data from vital and health statistics; no. 334. National Center for Health Statistics: Hyattsville, Maryland; 2003.

17. Sichert-Hellert W, Kersting M, Schöch G: Underreporting of energy intake in 1 to 18 year old German children and adolescents. Z Ernahrungswiss 1998, 37:242-251.

18. Merkiel S, Chalcarz W, Deptuła M: Porównanie aktywności fizycznej oraz ulubionych form spędzania czasu wolnego dziewczynek i chłopców w wieku przedszkolnym z województwa mazowieckiego, in Polish. (Comparison of physical activity and favourite ways of spending free time in preschool girls and boys from the Mazowsze region.). Rocz Panstw Zakl Hig 2011, 62:93-99.

19. Chalcarz W, Merkiel S, Hodyr Z: Nutritional status of preschool children from Pabianice. New Med (Wars) 2008, 12:29-35.

20. Kunachowicz H, Nadolna I, Przygoda B, Iwanow K: Tabele składu i wartości odżywczej żywności, in Polish. (Tables of food composition and nutritional value.). Warszawa: Wydawnictwo Lekarskie PZWL; 2005.

21. Cummings $\mathrm{JH}$, Stephen AM: Carbohydrate terminology and classification. Eur J Clin Nutr 2007, 61(Suppl 1):S5-S18.

22. Henry CJK: Basal metabolic rate studies in humans: measurement and development of new equations. Public Health Nutr 2005, 8(7a):1133-1152.

23. Food and Nutrition Board of the Institute of Medicine: Dietary Reference Intakes for energy, carbohydrate, fiber, fat, fatty acids, cholesterol, protein, and amino acids. Washington DC: The National Academies Press; 2005.

24. Food and Nutrition Board of the Institute of Medicine: Dietary Reference Intakes. Applications in dietary assessment. Washington DC: The National Academies Press; 2003.

25. World Health Organization: Diet, nutrition and the prevention of chronic diseases. Report of a Joint WHO/FAO Expert Consultation. Geneva: World Health Organization; 2003.

26. Merkiel S, Chalcarz W, Wegner M: Ocena jadłospisów przedszkolnych. Część I. Energia i makroskładniki, in Polish. (Assessment of preschool menus. Part 1. Energy and macronutrients.). Med Środ 2009, 12:75-80.

27. Jarosz M: Normy żywienia dla populacji polskiej - nowelizacja, in Polish. (Dietary reference intakes for the Polish population - amendment). Warszawa: Instytut Żywności i Żywienia; 2012. 
28. Kuczmarski RJ, Ogden CL, Guo SS, Grummer-Strawn LM, Flegal KM, Mei Z, Wei R, Curtin LR, Roche AF, Johnson CL: 2000 CDC growth charts for the United States: Methods and development. Vital Health Stat 2002, 11(246):1-190.

29. Barlow SE, the Expert Committee: Expert Committee recommendations regarding the prevention, assessment, and treatment of child and adolescent overweight and obesity: summary report. Pediatrics 2007 120(Suppl 4):S164-S192.

30. Merkiel S, Chalcarz W: The relationship between physical fitness, urine iodine status, and body-mass index in 6- to 7-year-old Polish children. Int J Sport Nutr Exerc Metab 2011, 21:318-327.

31. GOV.UK, the website of the United Kingdom. [https://www.gov.uk]

32. Centers for Disease Control and Prevention. [http://www.cdc.gov]

33. Glynn L, Emmett P, Rogers I: Food and nutrient intakes of a population sample of 7-year-old children in the south-west of England in 1999-2000 what difference does gender make? J Hum Nutr Diet 2005, 18:7-19.

34. Moreira P, Padez C, Mourão I, Rosado V: Dietary calcium and body mass index in Portuguese children. Eur J Clin Nutr 2005, 59:861-867.

35. Singh AS, Mulder C, Twisk JWR, van Mechelen W, Chinapaw MJM: Tracking of childhood overweight into adulthood: a systematic review of the literature. Obes Rev 2008, 9:474-488.

36. Fisher JO, Johnson RK, Lindquist C, Birch LL, Goran Ml: Influence of body composition on the accuracy of reported energy intake in children. Obes Res 2000, 8:597-603.

37. Livingstone MBE, Black AE: Markers of the validity of reported energy intake. J Nutr 2003, 133(Suppl 3):895S-920S.

38. Alexy U, Sichert-Hellert W, Kersting M, Schultze-Pawlitschko V: Pattern of longterm fat intake and BMI during childhood and adolescence - results of the DONALD Study. Int J Obes Relat Metab Disord 2004, 28:1203-1209.

39. Waling MU, Larsson CL: Energy intake of Swedish overweight and obese children is underestimated using a diet history interview. J Nutr 2009, 139:522-527.

40. Manios Y: Design and descriptive results of the "Growth, Exercise and Nutrition Epidemiological Study In preSchoolers": The GENESIS Study. BMC Public Health 2006, 6:32.

41. Huynh DTT, Dibley MJ, Sibbritt DW, Tran HTM: Energy and macronutrient intakes in preschool children in urban areas of Ho Chi Minh City, Vietnam. BMC Pediatr 2008, 8:44.

42. Sluijs I, Beulens JWJ, Van Der ADL, Spijkerman AMW, Grobbee DE, Van Der Schouw YT: Dietary Intake of Total, Animal, and Vegetable Protein and Risk of Type 2 Diabetes in the European Prospective Investigation into Cancer and Nutrition (EPIC)-NL Study. Diabetes Care 2010, 33:43-48.

43. Cheng G, Buyken AE, Shi L, Karaolis-Danckert N, Kroke A, Wudy SA, Degen $\mathrm{GH}$, Remer T: Beyond overweight: nutrition as an important lifestyle factor influencing timing of puberty. Nutr Rev 2012, 70:133-152.

44. Preis SR, Stampfer MJ, Spiegelman D, Willett WC, Rimm EB: Dietary protein and risk of ischemic heart disease in middle-aged men. Am J Clin Nutr 2010, 92:1265-1272.

45. Butte NF: Fat intake of children in relation to energy requirements. Am J Clin Nutr 2000, 72(Suppl 5):1246S-1252S.

46. Lagström $H$, Seppänen $R$, Jokinen $E$, Niinikoski H, Rönnemaa T, Viikari J Simell O: Influence of dietary fat on the nutrient intake and growth of children from 1 to $5 \mathrm{y}$ of age: the Special Turku Coronary Risk Factor Intervention Project. Am J Clin Nutr 1999, 69:516-523.

47. Lauer RM, Obarzanek E, Kwiterovich PO, Kimm SYS, Hunsberger SA, Barton BA, Van Horn L, Stevens VJ, Lasser NL, Robson AM: Efficacy and safety of lowering dietary intake of fat and cholesterol in children with elevated low-density lipoprotein cholesterol: The dietary intervention study in children (DISC). JAMA 1995, 273:1429-1435.

48. Lauer RM, Obarzanek E, Hunsberger SA, Van Horn L, Hartmuller WW, Barton BA, Stevens VJ, Kwiterovich PO Jr, Franklin FA Jr, Kimm SYS, Lasser $\mathrm{NL}$, Simons-Morton DG: Efficacy and safety of lowering dietary intake of total fat, saturated fat, and cholesterol in children with elevated LDL cholesterol: the Dietary Intervention Study in Children. Am J Clin Nutr 2000, 72(Suppl 5):1332S-1342S.

49. Shea $S$, Basch $C E$, Stein $A D$, Contento IR, Irigoyen M, Zybert $P$ : Is there a relationship between dietary fat and stature or growth in children three to five years of age? Pediatrics 1993, 92:579-586.

50. Shannon BM, Tershakovec AM, Martel JK, Achterberg CL, Cortner JA, Smiciklas-Wright HS, Stallings VA, Stolley PD: Reduction of elevated LDL-cholesterol levels of 4- to 10-year-old children through home-based dietary education. Pediatrics 1994, 94:923-927.
51. Law M: Dietary fat and adult diseases and the implications for childhood nutrition: an epidemiologic approach. Am J Clin Nutr 2000, 72(Suppl 5):1291S-1296S.

52. Schuchardt JP, Huss M, Stauss-Grabo M, Hahn A: Significance of long-chain polyunsaturated fatty acids (PUFAs) for the development and behaviour of children. Eur J Pediatr 2010, 169:149-164.

53. Chalcarz W, Merkiel S, Hodyr Z: Food behaviour in preschool children from Pabianice. New Med (Wars) 2009, 13:7-12.

54. Weker H, Rudzka-Kańtoch Z, Strucińska M, Maron A, Gozdalik E, Marcinkowska M, Klemarczyk W: Żywienie dzieci w wieku przedszkolnym. Ogólna charakterystyka sposobu żywienia, in Polish. (Nutrition of children at preschool age. General considerations and assessment of children nutrition). Rocz Panstw Zakl Hig 2000, 51:385-392.

55. Drewnowski A: Sensory preferences for fat and sugar in adolescence and adult life. Ann N Y Acad Sci 1989, 561:243-250.

56. Drewnowski A: Taste preferences and food intake. Annu Rev Nutr 1997, $17: 237-253$

57. Niinikoski $H$, Ruottinen S: Is carbohydrate intake in the first years of life related to future risk of NCDs? Nutr Metab Cardiovasc Dis 2012, 22:770-774.

58. Alexy U, Sichert-Hellert W, Kersting M: Associations between intake of added sugars and intakes of nutrients and food groups in the diets of German children and adolescents. Br J Nutr 2003, 90:441-447.

59. Gibson SA: Non-milk extrinsic sugars in the diets of pre-school children: association with intakes of micronutrients, energy, fat and NSP. Br J Nutr 1997, 78:367-378.

60. Kranz S, Smiciklas-Wright H, Siega-Riz AM, Mitchell D: Adverse effect of high added sugar consumption on dietary intake in American preschoolers. J Pediatr 2005, 146:105-111.

61. Øverby NC, Lillegaard ITL, Johansson L, Andersen LF: High intake of added sugar among Norwegian children and adolescents. Public Health Nutr 2004, 7:285-293.

62. Chalcarz W, Merkiel S: Wiedza żywieniowa rodziców dzieci przedszkolnych z Nowego Sącza i okolic. 2. Żywienie w profilaktyce chorób dietozależnych, in Polish. (Nutritional knowledge of parents of preschool children from Nowy Sącz and the vicinity. 2. Nutritional prevention of diet-related diseases). Żyw Człow Metab 2009, 36:390-395.

63. Merkiel S, Chalcarz W: Nutritional knowledge of the preschool staff from Nowy Sącz and the vicinity. Part 2. Nutritional prevention of diet-related diseases. New Med (Wars) 2010, 14:49-52.

64. Merkiel S, Chalcarz W: Wiedza żywieniowa rodziców dzieci przedszkolnych z Nowego Sącza i okolic. 1. Wiedza ogólna o żywieniu dzieci, in Polish. (Nutritional knowledge of parents of preschool children from Nowy Sącz and the vicinity. 1. General principles of nutrition during childhood.). Żyw Człow Metab 2009, 36:385-389.

65. Merkiel S, Chalcarz W: Nutritional knowledge of the preschool staff from Nowy Sącz and the vicinity. Part 1. General principles of nutrition during childhood. New Med (Wars) 2010, 14:44-48.

66. Drewnowski A: Dietary fats: perceptions and preferences. J Am Coll Nutr 1990, 9:431-435.

67. Wansink B, Cheney MM, Chan N: Exploring comfort food preferences across age and gender. Physiol Behav 2003, 79:739-747.

68. Zellner DA, Garriga-Trillo A, Rohm E, Centeno S, Parker S: Food liking and craving: a cross-cultural approach. Appetite 1999, 33:61-70.

69. Ritz P, Berrut G: The importance of good hydration for day-to-day health. Nutr Rev 2005, 63(6 Pt 2):S6-S13.

70. Manz F, Wentz A: The importance of good hydration for the prevention of chronic diseases. Nutr Rev 2005, 63(6 Pt 2):S2-S5.

71. Lambert J, Agostoni C, Elmadfa I, Hulshof K, Krause E, Livingstone B, Socha P, Pannemans D, Samartín S: Dietary intake and nutritional status of children and adolescents in Europe. Br J Nutr 2004, 92(Suppl 2):S147-S211.

doi:10.1186/1471-2431-14-197

Cite this article as: Merkiel: Dietary intake in 6-year-old children from southern Poland: part 1 - energy and macronutrient intakes. BMC Pediatrics 2014 14:197. 